\title{
CORRECTION
}

\section{Correction to: Durability assessment of some Cappadocian tuffs using factor analysis, multiple regression analysis, and analytical hierarchy process}

\author{
B. Ertas Deniz ${ }^{1} \cdot$ T. Topal ${ }^{2}$
}

Published online: 4 January 2022

๑) Springer-Verlag GmbH Germany, part of Springer Nature 2021

Correction to: Bulletin of Engineering Geology and the Environment (2021) https://doi.org/10.1007/s10064-021-02510-0

Originally, the author's family name in one of the references was cited incorrectly. The family name is Casanova Municchia and not Munuccihia.

The original article has been corrected.

The original article can be found online at https://doi.org/10.1007/ s10064-021-02510-0.

T. Topal

topal@metu.edu.tr

1 Disaster and Emergency Management Authority, Ankara, Turkey

2 Department of Geological Engineering, Middle East Technical, University (METU), Ankara, Turkey 